\title{
Glycogenic acanthosis on mouth clinically present as white plaque
}

\author{
Acantose glicogênica na boca clinicamente presente como placa branca
}

\author{
Maykon Kennedy SCHULZ \\ (iD) ORCID iD 0000-0002-3826-4082 \\ Mariel Ruivo BIANCARDI ${ }^{1}$ \\ (iD) ORCID /0000-0001-6766-642X \\ Darcy FERNANDES 1 \\ (iD) ORCID iD 0000-0002-0284-996X \\ Luciana Yamamoto de ALMEIDA² \\ (iD) ORCID iD 0000-0001-5403-4052 \\ Andreia BUFALINO ${ }^{1}$ \\ (D) ORCID iD 0000-0002-6714-6253 \\ Jorge Esquiche LEON ${ }^{3}$ \\ (iD) ORCID iD 0000-0002-9668-5870
}

\section{ABSTRACT}

Glycogenic acanthosis is a benign condition, commonly observed during endoscopic procedures in older patients, which present as slightly elevated whitish plaques often on the lower third of the oesophagus. Microscopically, glycogenic acanthosis is composed of hyperplastic squamous epithelium with intracytoplasmic glycogen deposits. The extraoesophageal glycogenic acanthosis is extremely rare, with only three case reports in the English-language literature. We report a white lesion showing glycogenic acanthosis-like features located on the left posterolateral border of the tongue, affecting a 56-year-old male patient. The medical history was non-contributory and the patient did not show any lesions during endoscopic examination of the oesophagus, stomach, and upper duodenum. Glycogenic acanthosis is a benign condition, which should be included in the differential diagnosis when assessing oral white lesions. It is important also to recognize this benign condition early and rule out the possibility of other more severe diseases, but further studies were necessary for better define their potential for persistence or recurrence, as observed in the current case.

Indexing terms: Diagnosis, differential. Glycogen. Mouth mucosa.

\section{RESUMO}

A acantose glicogênica é uma condição benigna, comumente observada durante procedimentos endoscópicos em pacientes idosos, e se apresenta como placas brancas levemente elevadas, freqüentemente encontrada no terço inferior do esôfago. Microscopicamente, a acantose glicogênica é composta por epitélio escamoso hiperplásico com depósitos de glicogênio intracitoplasmático. A acantose glicogênica extraesofágica é extremamente rara, com apenas três relatos de casos na literatura em língua inglesa. Apresentamos um caso com uma lesão branca diagnosticada como acantose glicogênica, localizada na borda póstero-lateral esquerda da língua, afetando um paciente do sexo masculino de 56 anos. A história médica não foi contribuitória e o paciente não apresentou lesões durante o exame endoscópico do esôfago, estômago e duodeno superior. A acantose glicogênica é uma condição benigna, que deve ser incluída no diagnóstico diferencial na avaliação de lesões brancas orais. É importante também reconhecer precocemente essa condição benigna e descartar a possibilidade de outras doenças mais graves, porém mais estudos são necessários para melhor definir seu potencial de persistência ou recorrência, como observado no presente caso.

Termos de indexação: Diagnóstico diferencial. Glicogênio. Mucosa Bucal.

\section{INTRODUCTION}

Glycogenic acanthosis (GA) is a benign lesion characterized by multifocal white plaques usually subtle, rounded elevations, often involving the lower oesophagus
[1]. Microscopically, it is composed of hyperplastic squamous epithelium with abundant intracellular glycogen deposits.

As any white lesions affecting the oral mucosa, this needs to be carefully investigated with all attention towards

\footnotetext{
${ }^{1}$ Universidade Estadual Paulista, Departamento de Diagnóstico e Cirurgia. Rua Humaitá, 1680, 14801-903, Araraquara, SP, Brasil. Correspondência para / Correspondence to: D FERNANDES. E-mail: <darcyfernandes@foar.unesp.br>.

${ }^{2}$ Universidade de São Paulo, Faculdade de Medicina, Departamento de Patologia. Ribeirão Preto, SP, Brasil.

${ }^{3}$ Universidade de São Paulo, Faculdade de Odontologia, Departamento de Estomatologia, Saúde Coletiva e Odontologia Legal. Ribeirão Preto, SP, Brasil. $\boldsymbol{\nabla} \mathbf{v}$

Como citar este artigo / How to cite this article

Schulz MK, Biancardi MR, Fernandes D, Almeida LY, Bufalino A. Glycogenic acanthosis on mouth clinically present as white plaque. RGO, Rev Gaúch Odontol. 2018;66(3):274-277. http://dx.doi.org/10.1590/1981-8637201800030000133422
} 
to oral leukoplakia (OL) since it is considered a potentially malignant disorder [2]. The diagnosis of $\mathrm{OL}$ is established by exclusion, eliminating all the others possible conditions such as frictional keratosis, lichenoid lesion, candidiasis, leukoedema, graft-versus-host disease, white sponge nevus, among others [3]. Mostly, the histopathological analysis becomes very important, which in close correlation with the clinical findings, allows establishing a diagnostic conclusion.

The extraoesophageal manifestation of GA is extremely rare, and to the best of our knowledge, there are only four extraoesophageal case reports, three cases involving the oral cavity and one involving the larynx [4-6]. In this study, our aim was to report a rare case of white lesion showing GA-like features affecting the lateral border of the tongue and emphasizing the differential diagnosis.

\section{CASE REPORT}

A 56-year-old white man was referred to the Oral Medicine Service for evaluation of a white patch in the oral cavity. The patient denied smoking and alcohol consumption or other habits and his medical history were non-contributory. According to the patient, a similar lesion had been removed 4 years ago in the same location. This previous excisional biopsy did not reveal any sign of dysplasia, being only followed up. On intraoral examination, there was a well-defined and asymptomatic white plaque with a fluffy surface, measuring $3.0 \mathrm{~cm}$ in diameter, located on the left posterolateral border of the tongue (figure 1A). There was no sign of chronic local trauma. Although it has an uncommon presentation, OL was the main hypothesis of clinical diagnosis. Our conduct was to perform an excisional biopsy. The microscopic analysis showed a hyperplastic squamous epithelium, showing prominent acanthosis in close transition with parakeratosis, which through Periodic acid-Schiff (PAS) with and without diastase stain revealed abundant intracytoplasmatic glycogen deposits (figure 2B-E). No cellular pleomorphism, nuclear hyperchromatism, mitotic figures or abnormalities were visualized. However, different from typical OL, the acanthosis and irregular parakeratosis were suggestive of a reactive process. The endoscopy examination did not show any alteration on the oesophagus, stomach, and upper duodenum. Considering the clinical aspect and the microscopical features, the diagnosis of glycogenic acanthosis was established. After 16 months of follow up, no signs of recurrence were observed.

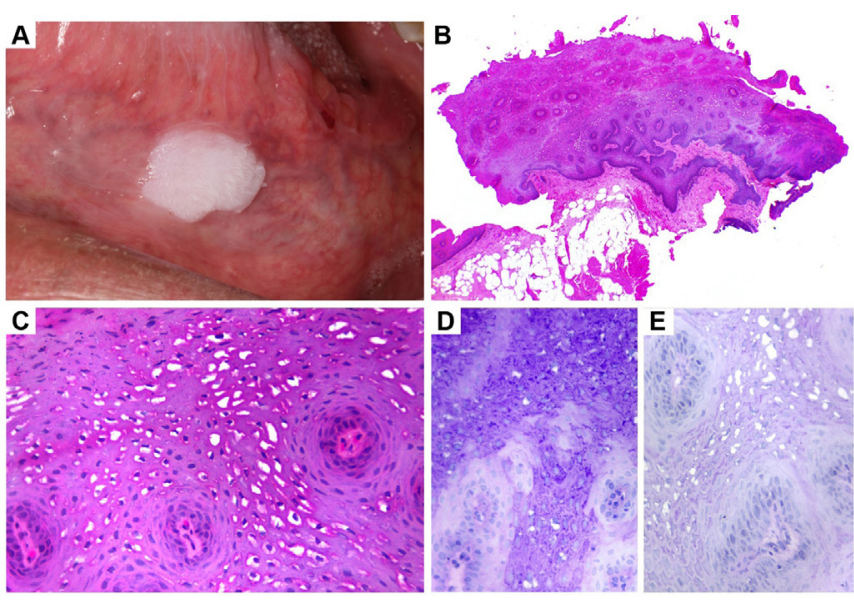

Figure 1. Clinical aspect of the lesion showing a plaque-like thickening of the mucosa on the left posterolateral border of the tongue.

Note: (A). The microscopic image of the lesion presenting surface epithelium with prominent acanthosis and clear keratinocytes filled with glycogen deposits (B and C, Hematoxylin-Eosin staining, original magnification X4 and X40, respectively), as demonstrated by periodic acid-Schiff (PAS) without and with diastase stain ( $D$ and $E$, PAS staining respectively without and with diastase, original magnification X40). The PAS with diastase stain was negative indicating abundant intracytoplasmatic glycogen deposits.

\section{DISCUSSION}

Glycogenic acanthosis was a term adopted by Rywlin and Ortega [7] in 1970 to refer to areas of mucosal thickening, usually seen on the lower oesophagus, characterized microscopically by epithelial hyperplasia with an accumulation of intracytoplasmic glycogen. Instead of $\mathrm{OL}$, it does not show any potential for malignancy. The oesophageal GA has become increasingly know on endoscopy examination, with some recent evidence to its association to the gastroesophageal reflux disease [8-10]. In this study, we reported a rare case of white lesion showing GA-like features on the tongue and we review the extraoesophageal case reports of GA published in the English-language literature (table 1).

Among all cases found, including our case, the median age at the time of diagnosis was 65 years, ranging from 53 to 79 years. Thus, an age-related, degenerative process should be considered in their etiopathogenetic mechanisms. Tongue involvement was observed in only two patients, being the lesion size not greater than $4.0 \mathrm{~cm}$ in diameter. Other oral sites may be affected by the glycogenic acanthosis, as the buccal mucosa [11].

The recognition of a similar standard of epithelial response in larynx and oesophagus suggest that epithelial hyperplasia associated with glycogen 
accumulation might be a non-specific pattern of epithelial response linked to site-specific injury changes [4]. In a previously published GA case, during a 5-year follow-up, no sign of malignant transformation was observed [6]. Curiously, in the current case, acanthosis and parakeratosis were observed. This latter may be due

Table 1. Extraesophageal case reports of glycogenic acanthosis.

\begin{tabular}{|c|c|c|c|c|c|c|c|}
\hline Authors & Year & Gender & Age & Country & Oral site & Size & Other findings \\
\hline Fyfe \& Garcia [4] & 1998 & Male & 79 & USA & Larynx & $2 \mathrm{~cm}$ & $\begin{array}{l}\text { Hypertension and } \\
\text { atherosclerosis }\end{array}$ \\
\hline Nishizawa et al. [5] & 2009 & Female & 53 & Japan & Gingiva & - & $\begin{array}{l}\text { Cowden } \\
\text { syndrome: } \\
\text { Colon polyposis, } \\
\text { lipoma, ovarian } \\
\text { cyst, thyroid } \\
\text { adenoma and } \\
\text { breast fibroma }\end{array}$ \\
\hline $\begin{array}{l}\text { Montebugnoli et } \\
\text { al. [6] }\end{array}$ & 2010 & Male & 72 & Italy & Tongue & $4 \mathrm{~cm}$ & No other findings \\
\hline Jinbu et al. [11] & 2013 & Male & 46 & Japan & $\begin{array}{l}\text { Buccal } \\
\text { mucosa }\end{array}$ & - & $\begin{array}{l}\text { Cutaneous } \\
\text { pruritus, } \\
\text { obsession, } \\
\text { depressive } \\
\text { state and stiff } \\
\text { shoulders }\end{array}$ \\
\hline
\end{tabular}

to the location of the lesion and the possible effects of chewing and swallowing, suggesting a reactive process.

Mucosal lesions showing similar features with GA have been reported in patients with Cowden's Syndrome [5], a genetic disorder characterized by multiple hamartomas, which affect multiple organs [12]. However, the current patient did not show any mucous or cutaneous lesions that would indicate a syndromic condition.

Oesophageal GA is found in $3.5 \%$ of the oesophageal endoscopic examinations [8]. Despite the name, there is no association between GA and abnormalities of glucose metabolism, such as diabetes9. During the examination, these lesions appear as whitegrey plaques, slightly elevated, usually measuring 2-10 $\mathrm{mm}$ of diameter [10]. Interestingly, different from previously published GA cases, the current case had a recurrence. Nevertheless, since this condition did not require any treatment, or it is reported in autopsies and postmortem studies, the rate of recurrence was not established yet.

In the differential diagnoses, the frictional keratosis was excluded since there was no sign of chronic local trauma. We considered $\mathrm{OL}$ as the principal clinical hypothesis since it is the most common oral potentially malignant disorder with a frequency of malignant transformation of $17-24 \%$ [13]. However, there was no associated risk factor, such as smoking and alcohol consumption, mainly associated with OL. Also, the histopathological analysis was not consistent with typical OL, which usually shows in hyperplastic lesions, acanthosis, hypergranulosis, and hyperorthokeratosis, maintaining the cellular architecture, different from the current case. A specific clinical subtype of $O L$ is verruciform or verrucous leukoplakia (VL). This condition is characterized by numerous pointed projections developed on the surface and may be similar with the current case [14]. However, different from GA, VL microscopically reveals varying degrees of epithelial dysplasia and hyperkeratosis. Oral verrucous hyperplasia $(\mathrm{VH})$ is a distinctive entity, which shows considerable clinical and histopathological resemblance to verrucous carcinoma (VC); however, different from VC, in oral $\mathrm{VH}$ its base lies above the line connecting the bases of the normal-appearing epithelium on both sides of the lesion. Oral $\mathrm{VH}$ has been recognized as a potentially malignant disorder, with a malignant transformation rate estimated of $10-20 \%[15,16]$. VC, a low-grade variant of squamous cell carcinoma, is often on the oral cavity. It is characterized by a diffuse, largely exophytic, superficial spreading highly keratinized lesion. It occurs mostly in elderly male, presenting slow growth and localized invasion, without metastatic potential [17]. Lastly, verrucous epidermal nevus (VEN), a congenital 
malformation or hamartoma derived from embryonic ectoderm, should be also considered. Oral involvement by $V E N$ is a rare manifestation, described as unilateral or midline papules or nodules, with a papillary or verrucous surface, usually affecting the tongue, lips, gingiva, buccal mucosa and palate [18].

\section{CONCLUSION}

Glycogenic acanthosis is not yet widely recognized in the field of dentistry. However, it is necessary to include it in the differential diagnosis list for white lesions of the oral mucosa. The clinicopathological presentation of the current case suggests a reactive or age-related process.

\section{REFERENCES}

1. Stern Z, Stern Z, Sharon P, Ligumsky M, Levij IS, Rachmilewitz D. Glycogenic acanthosis of the esophagus. A benign but confusing endoscopic lesion. Am J Gastroenterol.1980 Sep;74(3):261-3.

2. Lodi G, Porter S. Management of potentially malignant disorders: evidence and critique. J Oral Pathol Med. 2008 Feb;37(2):63-9. doi: 10.1111/j.1600-0714.2007.00575.x

3. Warnakulasuriya S, Johnson NW, van der Waal I. Nomenclature and classification of potentially malignant disorders of the oral mucosa. J Oral Pathol Med. 2007 Nov;36(10):575-80. doi: 10.1111/j.1600-0714.2007.00582.x

4. Fyfe BS, Garcia FU. Laryngeal glycogenic acanthosis presenting as leukoplakia. Arch Otolaryngol Head Neck Surg. 1998 Sep;124(9):1029-30. doi: 10.1001/archotol.124.9.1029

5. Nishizawa A, Satoh T, Watanabe R, Takayama K, Nakano H, Sawamura D, et al. Cowden syndrome: a novel mutation and overlooked glycogenic acanthosis in gingiva. Br J Dermatol. 2009 May;160(5):1116-8. doi:10.1111/j.1365-2133.2009.09072.x

6. Montebugnoli L, Felicetti L, Cervellati F, Foschini MP. Glycogenic acanthosis presenting as leukoplakia on the tongue. BMJ Case Rep. 2010;6:pii:bcr0120102634. doi: 10.1136/ bcr.01.2010.2634

7. Rywlin AM, Ortega R. Glycogenic acanthosis of the esophagus. Arch Pathol. 1970 Nov;90(5):439-43

8. Vadva MD, Triadafilopoulos G. Glycogenic acanthosis of the esophagus and gastroesophageal reflux. J Clin Gastroenterol. 1993 Jul; 17(1):79-83.

9. Rose D, Furth EE, Rubesin SE. Glycogenic acanthosis. AJR Am J Roentgenol. 1995;164:96-96. doi: 10.2214/ajr.164.1.7998577

10. Ghahremani GG, Rushovich AM. Glycogenic acanthosis of the esophagus: radiographic and pathologic features. Gastrointest Radiol. 1984;9(2):93-8. doi: doi.org/10.1007/BF01887812

\section{Collaborators}

MK SCHULZ, MR BIANCARDI, FERNANDES and LY ALMEIDA acquisition of data: laboratory or clinical/ literature search, analysis and interpretation of data collected and drafting of article and/or critical revision. D, conception and design of study/review/case series, acquisition of data: laboratory or clinical/literature search, analysis and interpretation of data collected and drafting of article and/or critical revision. A BUFALINO and JE LEÓN, conception and design of study/review/case series, acquisition of data: laboratory or clinical/literature search, analysis and interpretation of data collected and drafting of article and/or critical revision.

11. Jinbu $Y$, Kashiwazaki A, Ozawa M, Shinozaki Y, Kusama M Glycogenic acanthosis of the bilateral buccal mucosa. Report of a case. J Oral Maxillofac Surg Med Pathol. 2013 Apr;25(2):1713. doi: 10.1016/j.ajoms.2012.12.005

12. Eng C. PTEN: one gene, many syndromes. Hum Mutat. 2003 Sep;22(3):183-98. doi: 10.1002/humu.10257

13. Habiba U, Hida K, Kitamura T, Matsuda AY, Higashino F, Ito YM, et al. ALDH1 and podoplanin expression patterns predict the risk of malignant transformation in oral leukoplakia. Oncol Lett. 2017 Jan;13(1):321-328. doi: 10.3892/ol.2016.5379

14. Bouquot JE, Whitaker SB. Oral leukoplakia--rationale for diagnosis and prognosis of its clinical subtypes or "phases". Quintessence Int. 1994 Feb;25(2):133-40.

15. Shear M, Pindborg JJ. Verrucous hyperplasia of the oral mucosa. Cancer. 1980;46(8):1855-62. doi: 10.1002/1097-0142

16. Patil S, Warnakulasuriya S, Raj T, Sanketh DS, Rao RS. Exophytic oral verrucous hyperplasia: a new entity. J Investig Clin Dent. 2016 Nov;7(4):417-23. doi: 10.1111/jicd.12166

17. Hosseinpour S, Mashhadiabbas F, Ahsaie MG. Diagnostic Biomarkers in Oral Verrucous Carcinoma: A Systematic Review. Pathol Oncol Res. 2017 Jan;23(1):19-32. doi: 10.1007/s12253016-0150-x

18. Tesi D, Ficarra G. Oral linear epidermal nevus: a review of the literature and report of two new cases. Head Neck Pathol. 2010 Jun:4(2):139-43. doi:10.1007/s12105-010-0165-7

Received on: 11/11/2017 Final version resubmitted on: 19/12/2017 Approved on: 22/3/2018 